\title{
Sobre saberes e crenças: \\ o Livro de Mórmon
}

DoI

http://dx.doi.org/10.11606/ 2179-0892.ra.2018.145522

\section{Clara Flaksman}

- Universidade Federal da Bahia / Salvador, BA, Brasil

$\checkmark$ claramflaksman@gmail.com

RESUMO

Este artigo é fruto de uma experiência de um ano de pesquisa de campo em uma Igreja Mórmon localizada no Rio de Janeiro. Seu principal objetivo é descrever a maneira como os mórmons apresentam sua experiência com a divindade, a saber: como uma forma de conhecimento. Com isso, pretende-se discutir a oposição entre crença e saber na antropologia, além de uma reflexão sobre o papel da(o) etnógrafa(o) em uma pesquisa de campo.
PalavRas-chaVe

\section{Mórmons,} etnografia, crença, saber, pesquisa 


\section{INTRODUÇÃO}

Convidamos todos os homens de toda parte a lerem o Livro de Mórmon, ponderarem no coração a mensagem que ele contém e depois perguntarem a Deus, o Pai Eterno, em nome de Cristo, se o livro é verdadeiro. Os que assim fizereme perguntarem com fé obterão, pelo poder do Espirito Santo, um testemunho de sua veracidade e divindade. (...) Os que obtiverem do Santo Espírito esse divino testemunho saberão, pelo mesmo poder, que Jesus Cristo é o Salvador do mundo, que Joseph Smith é seu profeta nestes últimos dias e que A Igreja de Jesus Cristo dos Santos dos Últimos Dias é o reino do Senhor restabelecido na Terra, em preparação para a segunda vinda do Messias.

(Introdução do Livro de Mórmon - outro testamento de Jesus Cristo)

O objetivo deste artigo é abordar algumas questões que surgiram na minha experiência de campo numa igreja mórmon do Rio de Janeiro'. A principal questão advinda dessa pesquisa foi: como descrever a experiência dos mórmons com a divindade sem atribuí-la a outros fatores que não os que eles próprios julgam relevantes? A questão, nesse caso, está relacionada à problemática da crença na antropologia. Porém, a abordagem, neste caso específico, está ancorada em uma observação etnográfica, já que os mórmons com quem convivi afirmavam sempre que sua filiação àquela Igreja baseava-se em um saber. O contraste entre esse tipo de assertiva e a doutrina da Igreja Mórmon, qualificada com frequência como fantasiosa (tanto em público quanto em particular, como me asseguravam os meus interlocutores), gerou a reflexão que aqui apresento. A minha finalidade, portanto, é descrever esse sistema religioso como uma forma de conhecimento e tratá-lo, como fazem os membros da Igreja com os quais me relacionei, como um saber.

O trabalho de campo que me levou a refletir sobre essas questões ocupou o período de doze meses em que frequentei uma unidade da Igreja de Jesus Cristo dos Santos dos Últimos Dias, nome oficial da Igreja Mórmon, no Rio de Janeiro. Ao longo daquele ano, frequentei tanto as reuniões dos domingos como vários outros eventos, além das aulas do Instituto, o centro de estudos da Igreja, onde pude assistir, sempre aos sábados, a aulas sobre as escrituras.

\section{A IGREJA DE JESUS CRISTO DOS SANTOS DOS ÚLTIMOS DIAS}

A Igreja foi fundada, aliás restaurada, nos Estados Unidos da América, em 1830, por Joseph Smith, seu primeiro presidente e profeta revelador. Diz-se que foi restaurada porque, segundo o Livro de Mórmon, Jesus Cristo veio para a América pelo mar, logo após sua ressurreição, numa travessia que durou 40 dias, e fun-

1 Trabalho que resultou em minha dissertação de mestrado, intitulada Santos dos Últimos Dias: etnografia e pesquisa mórmon, defendida em 2007 no PPCAS/Museu Nacional, na qual este artigo se baseia. Costaria de agradecer à minha orientadora de mestrado, Antonádia Borges, pelos comentários e sugestões feitas durante a elaboração deste trabalho. Aproveito para agradecer também a Marcio Coldman pelas sugestões feitas à época, a Cecília Mello pelos comentários e sugestões feitos à primeira versão deste artigo e a Sergio Flaksman pela revisão do texto, assim como à Capes, que me concedeu uma bolsa de mestrado. 
dou uma igreja. Esta é a igreja que Joseph Smith viria a restaurar, quase 1.800 anos depois. $^{2}$

A história por trás dessa conexão através dos séculos está no Livro de Mórmon, tido como a tradução dos registros dos antigos habitantes da América pré-colombiana, possíveis descendentes de um patriarca vindo do Oriente Médio em busca dessa terra prometida. Hoje em dia, estima-se que os membros da IJCSUD em todo o mundo cheguem a mais de 14 milhões, segundo os registros oficiais da Igreja. Deste total, cerca de seis milhões estão nos EUA, espalhando-se os demais por outros 245 países. A sede da Igreja fica em Salt Lake City, Utah (EUA), de onde é dirigida por seu atual presidente e profeta revelador.

Embora a Igreja Mórmon professe uma religião tipicamente norte-americana, encontrou terreno fértil no Brasil. É curioso que uma Igreja cujos dogmas e história remontem de maneira tão direta aos Estados Unidos da América (e na qual o acesso dos negros ao sacerdócio era vetado até 1978) tenha encontrado tamanha aceitação entre os brasileiros. Segundo os registros oficiais, os primeiros mórmons, vindos dos EUA, chegaram ao Brasil em 1923. Os primeiros brasileiros conversos entraram para a Igreja em 1929. Hoje, são mais de um milhão. Há poucos anos, o Brasil tornou-se o terceiro país com mais mórmons no mundo (EUA e México ocupam os primeiros lugares) e o segundo em número de unidades da Igreja (depois apenas dos EUA). ${ }^{3}$

A estrutura da Igreja segue um padrão4: o presidente lidera uma estrutura hierárquica complexa, que se apoia nas congregações locais, lideradas por bispos. Além das congregações, classificadas como Estacas, Alas ou Ramos (dependendo do número que membros que as frequentam), há os Institutos de Religião, centros de pesquisa sobre o mormonismo onde são formados os missionários e onde qualquer membro (especialmente os jovens) pode frequentar aulas sobre os princípios doutrinários.

As reuniões dominicais são regulares e obedecem à mesma programação em todas as congregações do mundo. Têm a duração de três horas (das nove da manhã ao meio-dia) e abrangem: a Reunião da Sociedade de Socorro, para as mulheres, e a Reunião do Quórum do Sacerdócio, para os homens; a Escola Dominical (aula de Princípios do Evangelho), para os membros novos; a Reunião dos Rapazes e a Reunião das Moças; a Primária, para as crianças; e a Reunião Sacramental (para todos). As aulas ministradas em cada reunião dominical são idênticas, no conteúdo, em todas as igrejas do planeta. O tema da Reunião Sacramental, definido diretamente pela Sede da Igreja, também é sempre o mesmo no mundo inteiro.

A Igreja que frequentei fica em um bairro de classe média alta do Rio de Janeiro. Na época da minha pesquisa, reunia cerca de sessenta membros regulares. Destes, a grande maioria é de trabalhadores das redondezas. Havia portei-
2 Mais à frente, veremos em detalhe alguns fundamentos da Igreja.

3 Há discordâncias quanto ao número exato de mórmons no Brasil. O último censo, realizado em 2010, estimou que fossem pouco mais de duzentos mil. Já a própria Igreja, em um levantamento próprio, afirma que são mais de um milhão.

\footnotetext{
4 Padrão que pode ser percebido também na arquitetura das igrejas pelo mundo. Todas seguem um estilo de construção tipicamente norte-americano, com linhas retas, cores sóbrias e parcos elementos dispostos ordenadamente. A construção central é geralmente cercada por um jardim com poucas plantas, sempre bem cuidadas, e um pátio vazio ou com um ou dois bancos apenas.
} 
ros, empregadas domésticas, manicures e jardineiros. Muitos moravam numa comunidade do bairro formada por antigos trabalhadores residentes no terreno de uma grande instituição. Os membros da Igreja com renda familiar mais alta vinham de bairros distantes para ocupar algum posto que estivesse vago à época - o bispo, por exemplo, fora transferido de outra unidade, pois todos os homens que poderiam exercer essa função já haviam ocupado o posto. Como os dirigentes da Igreja não recebem qualquer tipo de remuneração, esses cargos são geralmente exercidos de maneira sazonal. ${ }^{5}$

\section{O MORMONISMO E A ANTROPOLOGIA}

São raros os estudos antropológicos sobre a Igreja Mórmon no Brasil. Até a data do presente trabalho, só havia duas teses ou dissertações sobre o tema. 0 primeiro deles, e consequentemente o mais antigo, é intitulado Os mórmons em Alagoas: religião e relações raciais, de Nádia Fernanda Maia de Amorim, publicado em 1986. A pesquisa de campo de Amorim divide-se em dois períodos: de 1966 a 1978 e de 1978 a 1981 — antes e depois da revelação que permitiu aos negros efetivamente fazerem parte da Igreja, tornando-se aptos a exercer o sacerdócio aarônico. O propósito da autora foi basicamente analisar a expansão do grupo estudado (um Ramo da Igreja em Maceió) nesses dois momentos, concluindo que a "alteração de posição com relação à raça" (1986: 25) era o fator explicativo por trás dessa expansão. Já o foco de Gilda Verônica Ludmila da Silva Catela, autora de "Juventude Divino Tesouro: Estudo comparativo sobre jovens mórmons das Igrejas San Martin (Rosário-Argentina) e Botafogo (Rio de Janeiro - Brasil)" é a juventude-ou, em suas palavras, a relação entre religião e juventude: "uma relação que interessa como espaço de classificações e construções, espaço organizado por determinadas práticas e representações" (1994: I).

Fenella Cannell, que se dedica há muitos anos ao estudo dos mórmons nos EUA, atribui a aparente ausência de interesse da antropologia pelo mormonismo à "relação complexa entre a teologia cristã e a teoria antropológica" (2005: $341)^{6}$. Para Cannell a antropologia não é tão secular quanto parece (e pretende) ser, tendo suas raízes fincadas no cristianismo — o que teria resultado num "preconceito", por parte dos antropólogos, quanto a toda prática cristã não-ortodoxa. Segundo ela, isso já ficava evidente na reação de muitos de seus colegas que, informados sobre o tema de sua pesquisa, contestavam de início que a Igreja Mórmon fosse cristã. Em outro artigo, a autora volta a se debruçar sobre o tema da orientação religiosa na ciência moderna. Segundo Cannell, a antropologia sempre se orientou pela ideia de que religião e secularismo são forças em guerra no mundo moderno, o que tanto explicaria o preconceito dos antropólogos contra o mormonismo como teria levado a maior parte dos interessados pelo tema
5 Odízimo (dez por cento dos rendimentos pessoais) pago pelos membros da Igreja, segundo me explicou uma amiga mórmon, serve para manter a estrutura da Igreja, tanto física quanto no que tange a eventos, funcionários etc. Nenhum posto da hierarquia da Igreja é remunerado. José, um membro da Igreja que eu frequentava, me afirmou certa vez que esse é o motivo pelo qual as reuniões da igreja se dão somente aos domingos. Nos outros dias da semana, a Igreja costuma permanecer fechada, podendo ser utilizada somente para eventos especiais. Mesmo os batismos a que assist durante a pesquisa ocorreram aos domingos, após a reunião.

6 A tradução, como em todos os outros casos de citações estrangeiras, é minha. 
da religião a buscar, para a existência desta, uma explicação baseada em fatores sociais. Entretanto, Cannel acredita que nos últimos tempos vem sendo criado um 'interstício' que permite pensar a religião sem que o estudioso precise comprometer-se de antemão com uma posição religiosa ou secular (Cannell 2017).

Cannell afirma que

por não propor uma resposta para as questões teológicas mais importantes ligadas à veracidade da existência de Deus, esse método antropológico sugere um procedimento intermediário, no qual qualquer posição antirreligiosa seria também não-antropológica (2017: 12).

Embora a autora se refira apenas ao estudo de Charles Taylor (A Secular Age), creio que essa posição poderia ser endossada ainda por Bruno Latour, para quem qualquer questão ligada à veracidade dos mistérios religiosos (a virgindade de Maria, por exemplo) são "erros de categorização" que produzem a "crença na crença" (2004: 356). O valor da verdade, nesse caso, dependeria do contexto de sua enunciação, que teria como principal objetivo provocar uma mudança, em vez de revelar, informar ou provar a veracidade de algum fato. Não caberia à antropologia, portanto, desvendar a verdadeira natureza desse tipo de enunciado. Ao aceitar fazê-lo, estaria — para usar um vocabulário definido pelo próprio autor - tratando como referência o que existe como reprodução e que, portanto, tem "condições de felicidade" diversas (Latour 2013). O recomendável, em lugar disso, é ter em mente que "a verdade nunca se encontra na correspondênciaseja entre as palavras e as coisas, no caso da ciência, ou entre original e cópia, no caso da religião - , mas em encarregar-se da continuidade do fluxo, prolongar num passo a mais a cascata das mediações" (2004: 371-372). O modo de fala religioso, portanto, exigiria uma 'condição de verdade' particular, que Latour aproxima do discurso amoroso - já que tem como objetivo trazer o interlocutor para perto ${ }^{7}$. A religião, portanto, fala a partir de coisas sensíveis ao modo como se fala delas. "Esses modos de fala ou bem evocam o espírito que declaram, e são verdadeiros, ou não o fazem, e são menos que falsos" (2004: 351).

Tomar a religião como um modo de enunciação, como propõe Latour, e a partir daí buscar suas "condições de verdade" (Latour apud Ciumbelli 2011: 328), parece um caminho frutífero para se falar do mormonismo, que tem como uma de suas características o estabelecimento de um canal de comunicação direta com o divino. Além disso, quem instaura essa relação deve torná-la pública através de discursos que a atualizem e fortaleçam, ao mesmo tempo em que servem de exemplo para outros. Toda reunião na Igreja tem um momento reservado aos discursos, sempre do púlpito. Elisângela, uma amiga da Igreja, explicou que "quando a gente sobe lá, está inspirada. A gente fala, mas é Deus que inspira".

7 Ao contrário da ciência que, como define Ingold, "continua a basear a sua legitimidade no recurso aos dados, que são repetidamente verificados e reverificados, numa busca incessante pela verdade, por meio da eliminação do erro" (2011: 15). 
O discursante, enquanto fala, atualiza as escrituras - normalmente o ponto de partida dos discursos - , acrescentando sua marca autoral a textos que, para ele, são sagrados. E, como me disse Elisângela: "Em que outra igreja a gente pode falar assim? Nas outras igrejas a gente só ouve. Aqui a gente pode falar os nossos pensamentos".

\section{TESTEMUNHO}

Uma das vezes em que fui ao Instituto de Botafogo, no Rio de Janeiro, vi no mural de recados uma carta de um missionário para os membros de sua Ala. A carta dizia, em meio a comentários sobre a missão:

Todos devemos nos comportar segundo o padrão e obedecer a Deus. A missão éa forma mais nobre de servi-lo. Vocês devem seguir com suas obrigações na Igreja, sempre servindo ao Pai Celestial da melhor maneira possivel. Digo isso do fundo do meu coração, da mesma maneira que sei do fundo do meu coração que esta é a Igreja Verdadeira, que Joseph Smith esteve com o Pai Celestial e com seu filho Jesus Cristo, e que o Livro de Mórmon é a tradução mais completa da Bíblia.

O missionário que escreveu a carta, como todos os mórmons que conheci, usa sempre a mesma palavra para se referir à veracidade da Igreja: ele sabe que a Igreja é verdadeira, assim como sabe que o Livro de Mórmon é verdadeiro e que Joseph Smith era um profeta de Deus. Emerson, o bispo da Igreja que frequentei, explicou-me que sabe porque isso Ihe foi revelado direta e individualmente por Deus, através do Espírito Santo.

Um dos fundamentos do mormonismo é que todos podem comunicar-se com Deus sem intermediários. Para tornar-se membro da Igreja, a pré-condição é justamente ter estabelecido um canal de comunicação direta com Deus. Esse canal direto surge a partir de uma pergunta: antes de se batizar, todo candidato a membro da Igreja deve ler pelo menos um trecho do Livro de Mórmon e perguntar diretamente a Deus se o Livro é verdadeiro. Só depois de uma resposta positiva é que o candidato pode receber a primeira das ordenanças sacramentais, o batismo. Por esse motivo, só pessoas com mais de oito anos podem se batizar: para os mórmons, antes dessa idade ninguém pode estar seguro de ter recebido a resposta divina.

Todo membro da Igreja, ao ouvir de Deus a primeira resposta positiva, que torna possível toda uma cadeia de confirmações - do Livro de Mórmon, da Igreja e do caráter profético de Joseph Smith - , torna-se capaz de um testemunho. Tive a oportunidade de escutar inúmeros desses testemunhos, já que em todo primeiro domingo do mês a Reunião Sacramental é uma Reunião de Testemunho. 
Neste dia, após o sacramento, o púlpito se abre para quem quiser prestar seu testemunho, que pode versar sobre assuntos vários, mas sempre se encerra com a recapitulação da sequência de verdades confirmadas pela primeira, revelada por Deus a cada um, como na carta do missionário de que falei acima: "Sei que esta é a Igreja verdadeira, da mesma maneira que sei que o Livro de Mórmon é verdadeiro e que Joseph Smith é um profeta de Deus na Terra."

Muitas vezes pedi a membros da Igreja que me contassem seus batismos e todo relato começava no momento em que perguntaram a Deus se o Livro de Mórmon era verdadeiro. Ao receberem a resposta positiva, ganhavam o seu primeiro testemunho, que lhes dava a certeza da vontade de batizarem-se. A resposta de Deus vem de várias maneiras: uns a escutam diretamente, em palavras, nas suas cabeças; outros experimentam uma sensação boa, confirmação de que a resposta é positiva. O saber, aqui, está relacionado ao sentir, e é a partir dele que os mórmons ordenam a realidade de seu universo. Perguntados sobre a resposta, meus interlocutores sempre ressaltavam que um diálogo obviamente existia, lembrando que sempre havia a possibilidade de uma resposta negativa, embora nenhum deles soubesse de algum caso assim. No entanto, a mera suposição dessa possibilidade mostra que, para eles, não havia a premissa de um sujeito universal de conhecimento. A inseparabilidade entre crença (geralmente associada a um fator subjetivo) e saber (comumente associado a fatores objetivos, portanto universais) impossibilita uma análise que suponha a existência de uma racionalidade universal. Penso que, em uma análise como essa, é mais coerente trabalhar com a formação de um sujeito capaz de saber de uma maneira específica. Ingold, ao analisar o modo de conhecimento dos monges medievais, demonstra como "o saber dependia de ver, e as duas coisas seguiam trajetórias de movimento" (2011: 19). Buscava assim formular, para o conhecimento ocidental, maneiras de romper a barreira que ele próprio ergueu entre o mundo e o modo como o imaginamos e representamos: "cicatrizar a ruptura entre o ser e o saber" (2011: 29).

Apresento a seguir alguns elementos que compõem o aprendizado mórmon - que poderia ser definido, a meu ver, como um aprendizado por impregnação, já que ensina cada um, em última instância, a (se) pensar como um mórmon.

\section{APRENDER PARA PERGUNTAR}

Logo que cheguei à unidade da Igreja onde fiz a minha pesquisa, fui apresentada à dupla missionária da época, formada por uma norte-americana e uma brasileira, que logo marcou um encontro para uma primeira conversa - na verdade, a primeira da série de palestras normalmente usadas para arrebanhar novos membros para a Igreja. 
Ao longo da minha pesquisa, convivi com seis diferentes pares de missionários. Todos os componentes, com uma única exceção, dedicavam tempo integral à sua missão - que pode durar entre dezoito e vinte e quatro meses. Um missionário nunca sabe seu destino de antemão e dificilmente permanece mais de três meses na mesma unidade, podendo ser transferido a qualquer momento. Um longo período longe de casa, com destino incerto, cumprindo jornadas extensas de trabalho sem remuneração alguma. O que pode parecer um sacrifício me foi descrito como um presente, pois, como me explicou Sister Moraes, a brasileira da primeira dupla com que convivi, "o missionário é um escolhido". O tempo da missão é um hiato em seu dia-a-dia, permitindo-Ihes reconfigurar sua identidade. Os missionários não podem usar seus prenomes durante o período da missão — todos são referidos pelo último sobrenome, antecedido pelo termo Elder (no caso dos homens) ou Sister (no caso das mulheres). É essa a denominação que figura nos crachás que distinguem todo missionário mórmon. Além disso, precisam afastar-se da vida cotidiana, só sendo autorizados a escrever para parentes e amigos uma vez por semana; telefonemas, só em datas festivas, como Natal e aniversários.

Os missionários são a face mais visível do complexo sistema de ensino da Igreja: cabe a eles a tarefa de ensinar aos pesquisadores - como eu. Todo pesquisador tem um missionário ao seu lado. A diferença, no meu caso, residia na maneira de aprender. Portadora de uma determinada concepção de pesquisa, eu esperava respostas para as minhas perguntas, mas os missionários me respondiam com palestras. Tentei sem sucesso interrogá-los, mas não consegui sequer descobrir seus nomes próprios. Com o passar do tempo, percebi que meu aprendizado sobre os missionários não seria linear, dos meios para os fins. O que eu tinha a aprender com eles não estava só no conteúdo das palestras, mas também nos seus métodos de ensino: os hábitos de pensamento (Bateson, 1972) que pairavam na atmosfera dos nossos encontros, fundamentando nossa relação, eram indissociáveis do que significa pesquisar para os mórmons.

Nesse mesmo texto, Gregory Bateson estabelece a diferença entre proto-learning e deutero-learning - em que o primeiro representa o gradiente de um ponto qualquer em uma curva de aprendizado e o segundo a mudança progressiva de inclinação deste gradiente. A cada nova série de experimentos de aprendizado, a curva do gradiente se inclina mais, ou seja, o sujeito aprende cada vez mais depressa. Ao longo do tempo vamos aprendendo a aprender e adquirimos o hábito de ordenar as sequências de pensamento de uma certa maneira. O paralelo entre a teoria de Bateson e o ensino missionário se dá justamente na identificação de uma curva de (meta)aprendizado: ao longo das palestras missionárias, supõe-se que o pesquisador vá adquirir certos hábitos de pensamento que balizam os conceitos básicos relacionados à condição de mórmon. Penso que 
muitos desses hábitos estão relacionados à questão do saber mórmon, da busca da verdade revelada a cada um por uma fonte externa, divina e infalível. Em nenhum momento os missionários incentivam o pesquisador a questionar-se, confrontando o aprendizado mórmon com seu saber anterior. O pesquisador não precisa saber nada, nem acreditar em nada de antemão: basta-lhe perguntar a Deus se o Livro de Mórmon diz a verdade.

Esse sistema é, ao mesmo tempo, unívoco e dúbio, pois poderíamos argumentar que, para perguntar a Deus, é necessário acreditar n'Ele. Conversei sobre isso com Jonas, um jovem membro da Igreja que se preparava para sair em missão. Aliás, os mórmons que conheci sempre receberam bem conversas como esta, característica também assinalada por Cannell, que conta como, durante sua pesquisa anterior sobre o catolicismo, os padres católicos sempre respondiam a suas perguntas existenciais dizendo "é um mistério", enquanto os mórmons que entrevistou posteriormente jamais se furtaram a essas questões. E define esse comportamento como um "compromisso com as formas de saber" (2017: 9).

Jonas me explicou que a resposta para essa questão era simples: bastava perguntar a Deus se Ele é verdadeiro. A resposta de Deus, segundo Jonas, tira de uma só vez toda dúvida que possa existir. Ee é nessa ciranda que se configura o hábito do pensamento mórmon; nesse interlocutor externo e infalível que responde a cada uma das nossas perguntas, sem margem para dúvida. ${ }^{8} \mathrm{O}$ tipo de comunicação estabelecido pelos mórmons que conheci, além de construir um mundo paralelo aos desafios mundanos, garante que a pergunta seja constantemente renovada - dirigida a Deus, que está além dos confrontos humanos.

A contradição entre fé e sabedoria, no caso desse interlocutor invisível, está na força motriz da pergunta. Por mais que se tente objetivar o caminho a ser seguido, o ato de perguntar a Deus é o primeiro degrau da personificação divina. $A$ passagem do invisível para o mundano, ainda que guiada por princípios objetivos, não se dá sem um ato de subjetivação. O que talvez nos caiba aqui é postular a fluidez dessa fronteira entre subjetivo e objetivo, evitando ver neles esferas opostas ou incompatíveis e, nesse sentido, apaziguar a busca de determinantes, causas e efeitos, desviando o foco para as surpresas que podem emergir de cada um, que organiza à sua maneira esses múltiplos elos.

Nas palestras missionárias, os missionários ensinam, basicamente, a maneira correta de fazer a pergunta, de estabelecer um contato direto com Deus. O pesquisador precisa aprender para perguntar - e, assim, aprende a ser mórmon.
8 Ao longo dessa

mesma conversa, Jonas me ofereceu uma descrição de como, para ele, essa forma de conhecimento pode ser construída: "A gente pensa que está cercado por uma esfera de cristal; só que quando a gente resolve abrir os olhos, a gente vê que essa esfera não existe de verdade. Existe um molde dela. $O$ que a gente tem que fazer é desenhar os cacos, o contorno dos cacos, e eles vão aparecendo. Conforme a gente vai desenhando esses cacos, a gente vai desenhando essa esfera à nossa volta, até que ela fica uma esfera perfeita, redonda, de cristal. A gente fica ali dentro daquele pequeno mundo; de lá, a gente pode ver as coisas sem ser afetado por elas."

\section{UMA PESQUISADORA OFICIAL}

No meu primeiro encontro com as missionárias, marcamos uma palestra para dali a alguns dias. A partir desse momento, tornei-me uma pesquisadora, título 
que recebe quem assiste às palestras para conhecer a Igreja. Levei algum tempo até perceber que era por esse motivo que me chamavam de "pesquisadora", e que eu justificar minha presença dizendo que fazia uma pesquisa só fazia aumentar essa confusão. Só fui perceber meu erro quando, na volta de uma convenção estadual da Igreja, João, um senhor que frequentava a mesma Igreja onde eu fazia pesquisa, sentou-se ao meu lado no ônibus e perguntou "Quando vai ser o seu batismo?" Respondi que estava fazendo uma pesquisa, e ele me disse "Eu sei que você é uma pesquisadora. Mas quando vai se batizar?" Nesse momento, a missionária Sister Ramos, que escutava a conversa, interveio. "Ela não é uma pesquisadora", tomou para si a resposta: "É uma pesquisadora oficial."

Depois disso, passei a empregar esse título, até perceber a falta de sentido dessa distinção: eu era, ao mesmo tempo, uma pesquisadora e uma pesquisadora oficial - não devido a qualquer tipo de (sub)intenção quanto à Igreja, mas porque, durante o trabalho, era vista das duas maneiras pela maioria dos mórmons com quem convivia. Além disso, esse equívoco não se prende a uma diferença no significado do termo, e sim a uma peculiaridade do cosmos mórmon, onde a intenção de "pesquisar" indica uma inclinação a participar, ou seja, a entrar na religião.

No dia marcado, encontrei-me com as missionárias numa padaria e fomos juntas para a Igreja, que estava vazia. A palestra que as missionárias me deram neste primeiro encontro, numa sala com algumas carteiras e um quadro negro, era intitulada "A Igreja Verdadeira". Depois de uma oração, disseram-me que iam me transmitir a primeira das mensagens que eu receberia, o relato do encontro com Deus e Jesus Cristo em que Joseph Smith teve sua primeira revelação e foi exortado a restaurar a Igreja de Cristo.

No momento em que Sister Purey, a missionária americana, falou em restauração, Sister Ramos reiterou seu testemunho. "Eu sei que Joseph Smith falou com o Pai Celestial e fico muito feliz de ele ter feito isso por mim. Eu sei que ele falou com o Anjo Morôni, que indicou onde estavam as Placas de Mórmon." Assim, as duas me asseguravam da veracidade do que me diziam, confirmada a cada uma por uma revelação pessoal.

Ao fim da mensagem, mostraram-me algumas imagens de Joseph Smith e seu encontro com o Anjo Morôni, perguntando se eu me sentia bem ao olhá-las. Depois que respondi positivamente, Sister Purey me perguntou: "Você acredita em Joseph Smith?" Era uma pergunta genérica, e respondi que sim. Então ela continuou: "Então você acredita que Joseph Smith encontrou o Anjo Morôni, que lhe indicou o local exato das Placas de Mórmon, e que o Livro de Mórmon é verdadeiro?"

Frente à minha relutância, Sister Purey disse: "É por isso que vamos te dar um Livro de Mórmon. Para que você leia e descubra por si mesma se o que Joseph Smith falou é verdade. No Livro de Mórmon, Joseph Smith diz que, se você quiser saber se o Livro é verdadeiro, é só perguntar para o Pai Celestial e Ele te 
responde. Você vai perguntar?" Demorei um pouco e respondi: "Não sei."

As missionárias me deram então um Livro de Mórmon e me ensinaram os passos a seguir até perguntar a Deus se o Livro era verdadeiro. Se eu perguntasse da maneira correta, Deus me responderia com uma revelação. Depois disso, não houve uma só vez que eu tenha ido à Igreja e alguém não me inquirisse se eu já havia feito a pergunta.

É importante ressaltar que a primeira confirmação divina engendraria uma série de outras: se o Livro fosse verdadeiro, a Igreja era verdadeira; se a Igreja fosse verdadeira, Joseph Smith era mesmo um profeta. A confirmação vinda de Deus atesta, portanto, que o Livro, como todo seu conteúdo, é verdadeiro. Como a história relatada no Livro de Mórmon estende-se aos primórdios da humanidade, a palavra de Deus atestaria também a veracidade da história do mundo mórmon, como veremos a seguir.

\section{A TERRA PROMETIDA}

Perto do tempo em que Jesus deve vir, os santos fiéis construirão uma cidade de retidão, uma cidade de Deus, chamada Nova Jerusalém. O próprio Jesus Cristo governará ali. Embora essa cidade ainda não esteja construída, o Senhor disse que o será no estado de Missouri, nos Estados Unidos.

(Princípios do evangelho: 258)

Na primeira vez que fui à Igreja, chamou-me a atenção um quadro no mural da entrada. Nele, Jesus Cristo - de túnica e capa brancas - prega para várias pessoas de uma suposta civilização pré-colombiana. Do lado direito, há uma ruína, com uma palmeira em meio às paredes desabadas. No meio do quadro, um pouco mais atrás, vê-se uma pirâmide. $A$ imagem é uma reprodução de uma

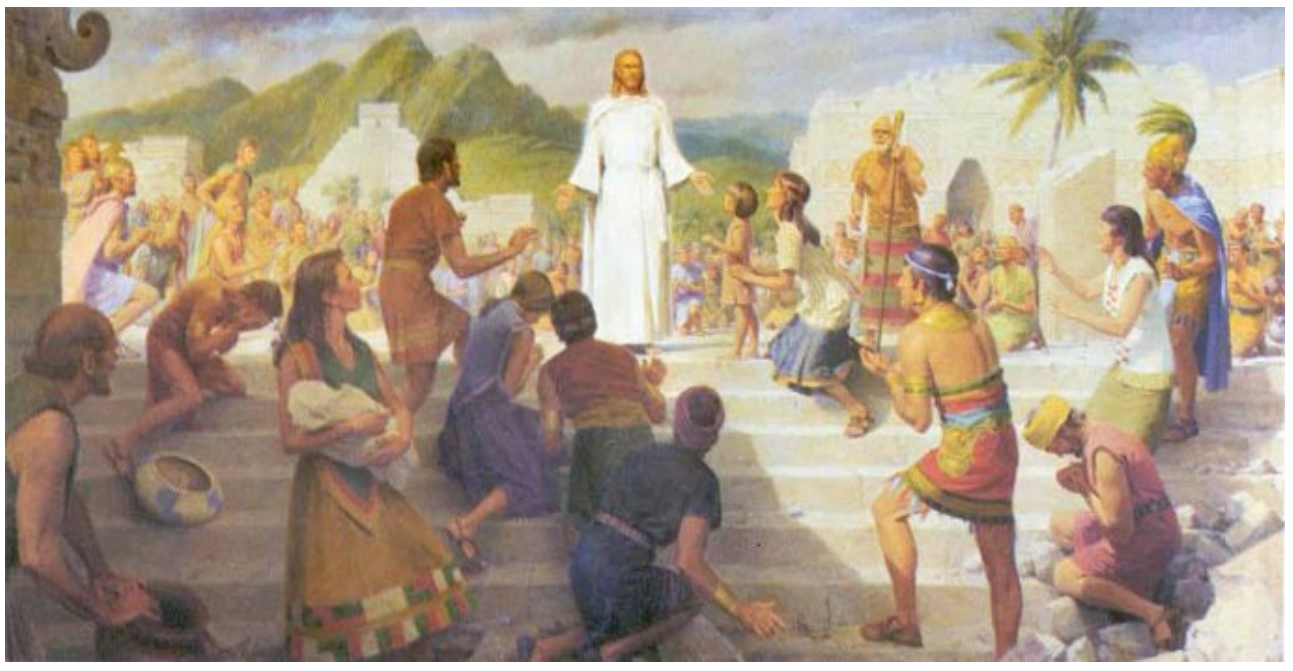

\section{Figura 1}

Jesus Cristo visita as Américas, pintura de John Scott 
pintura intitulada "Jesus Cristo visita as Américas", e eu tornaria a encontrá-la em diversos lugares - entre eles, diversos livros da Igreja (incluindo o Livro de Mórmon) e as paredes do Instituto. ${ }^{9}$

Alguns dias depois de ter assistido à primeira palestra, estive com as missionárias na Reunião de domingo e marcamos um segundo encontro. Neste dia, logo que entramos na sala, Sister Ramos escreveu no quadro negro: História do mundo mórmon.

Nesta aula, tomei conhecimento da primeira parte do Livro de Mórmon, em que a narrativa começa com a chegada de Leí às Américas, um patriarca vindo da Terra Santa, seiscentos anos antes de Cristo. Após sua morte, já na terra prometida, seus filhos Néfi e Lamã se separam, dando origem aos dois principais povos americanos da época: nefitas e lamanitas. Trezentos anos depois, uma guerra teria ocorrido entre esses dois povos, guerra que se estende até a vinda de Jesus à América, durante os quarenta dias entre suas ressurreição e ascensão. ${ }^{10}$ Advém um período de paz que se estende até 231 d.C., quando nefitas e lamanitas tornam a separar-se. Noventa anos mais tarde, irrompe uma nova grande guerra entre nefitas e lamanitas, cuja última batalha se trava em 385, aos pés do Monte Cumorah. Lá, o último comandante dos nefitas, chamado Mórmon, teria escondido as placas onde registrara o resumo das "grandes placas de Néfi" (nas quais este havia gravado a história de sua família). Os nefitas saem derrotados, mas Morôni, filho de Mórmon, sobrevive, e registra o legado de seu pai em placas que enterra junto às dele no cume do Monte Cumorah. Mais tarde, Morôni retorna, na forma de anjo, para revelar a Joseph Smith a localização das placas. Entre a morte de Morôni, no ano de 412, e o nascimento de Joseph Smith, 14 séculos mais tarde, não houve profetas sobre a Terra - foi "a grande apostasia"." Todo templo Mórmon traz no topo uma estátua do Anjo Morôni tocando uma trombeta, anunciando o fim do período de apostasia.

Crapanzano (2000) qualifica os cristãos fundamentalistas que estudou como "literalistas", tendo em vista sua leitura estrita da Bíblia, considerada uma revelação. Os mórmons que conheci têm a mesma relação com suas escrituras: a Bíblia, o Livro de Mórmon e os livros Doutrina \& convênios e Pérola de grande valor. A diferença é que, para o mormonismo, as palavras dos profetas também são escrituras. Certa vez ouvi João, o membro da Igreja que perguntara sobre o meu batismo, dizer em seu testemunho que "mais importantes que as palavras escritas são as revelações sobre elas, o sentimento de saber que elas são verdadeiras". Ainda que os mórmons sejam literalistas quanto aos textos sagrados, a revelação divina confirma para eles a verdade das escrituras, acima de qualquer dúvida.

Em 1997, a Smithsonian Institution publicou um memorando sobre o Livro de Mórmon, afirmando, entre outras coisas, que na América "não houve qualquer contato com os antigos egípcios, hebreus ou outros povos da Ásia Ocidental ou
9 Cannell (2013: S81) chama a atenção para o fato de que o Jesus Cristo da iconografia mórmon é ressurrecto. De fato, muitas vezes os membros da Igreja chamavam a minha atenção para o fato de que "o nosso Cristo não é aquele pendurado na cruz".

10 Na versão mórmon do Novo Testamento usa-se esse prazo (o que, segundo a Bíblia é controverso). De acordo com o Livro de Mórmon, após a sua ressurreição, Jesus aparece para os nefitas e lamanitas três vezes fazendo inúmeras profecias e operando milagres; uma das profecias diz respeito a Joseph Smith. Segundo a profecia, a nação de Israel seria reunida quando o Livro de Mórmon aparecesse; nesse momento, a Igreja seria restaurada - a verdadeira Igreja de Jesus Cristo. Santos são aqueles que seguem o evangelho restaurado; os últimos dias são os que vivemos. Vem daí a ordem do profeta atual para que os mórmons sempre tenham armazenados em suas casas alimentos e gêneros de primeira necessidade.

11 O significado principal da palavra apostasia é "afastamento generalizado da verdade", segundo o endereço oficial da Igreja (www.mormon. org). Segundo o Dicionário Houaiss da Língua Portuguesa, a palavra, de raiz grega que remete a "distanciar-se, separar-se", define-se como “1. renúncia de uma religião ou crença, abandono da fé (esp. da cristã); renegação 1.1 rel quebra de votos, abandono da vida religiosa ou sacerdotal, sem autorização superior 2. p. ext. ato de renunciar (a partido, doutrina, teoria etc.)". (a data de acesso é maio de 2007 - não sei como acrescentar esta informação) 
do Oriente próximo." Muitos mórmons, principalmente nos EUA, publicaram respostas à Smithsonian que, depois de uma série de correções, acabou por mudar sua posição oficial em 2001: "O Livro de Mórmon é um documento religioso, não um guia científico. A Smithsonian Institution jamais o utilizou em pesquisas arqueológicas, e qualquer informação contrária é incorreta."

A resposta da Smithsonian gerou controvérsia ${ }^{12}$ entre muitos membros da Igreja, divididos entre as duas versões históricas da verdade (cf. Veyne, 1984). Embora haja muitas discussões sobre o tema na Internet, as conversas que tive com membros da Igreja que frequentei geralmente seguiam outro caminho. José, um jovem membro da Igreja, certa vez me disse que, para ele, as duas versões sobre o povoamento da América não eram incompatíveis. "A gente não pode negar o que a ciência provou", ele me disse, "mas também não pode negar uma coisa que a gente sabe que é verdadeira". Já Rosana, uma das professoras, certa vez afirmou durante a aula de Princípios de Evangelho: "Vocês não acreditam nessa história de que o homem veio do macaco, né? Essa hipótese é absurda. Nós sabemos que o homem, o homem como nós somos hoje, foi colocado na Terra pelo Pai Celestial." A oposição entre documento religioso e guia científico, portanto, parece ter o seu sentido deslocado quando confrontada com o saber mórmon. ${ }^{13}$

Crapanzano (2000) encontrou diversos criacionistas empenhados em obrigar as escolas a lecionarem sua teoria sobre o surgimento do homem como uma versão alternativa à evolução. Ele conta que "foi só mais tarde, quando cheguei a um entendimento melhor do pensamento evangélico, que percebi que os criacionistas (...) tinham uma compreensão totalmente diversa do tempo e da história e, portanto, da ciência" (2000: 189). A conclusão de Crapanzano - de que está diante de outra concepção de ciência - me parece insuficiente para tratar do problema em questão aqui, já que em nenhum momento escutei dos mórmons com quem convivi qualquer menção a uma "ciência mórmon". De fato, existe uma diferença crucial entre a ciência ocidental e o saber mórmon: o lugar fundamental ocupado por Deus - não como presença etérea, mas como um espírito eterno dentro de um corpo tangível (Princípios do evangelho: 6): um ser invisível aos nossos olhos mortais, mas feito de matéria e capaz de manipular a matéria. Deus (como suas manifestações) é personagem ativo da história do mundo mórmon, de seu saber e, acima de tudo, da vida cotidiana.

\section{JOSEPH SMITH}

Em todas as igrejas onde estive, encontrei sempre junto à porta um retrato de Joseph Smith: um homem de trinta e poucos anos, de barba feita, olhos azuis e cabelos louros presos num rabo-de-cavalo, com um olhar que mira o infinito.
12 Algo que Fennella Cannell prefere denominar "especulação", que segundo ela pode ser considerado "uma categoria mórmon” (2013: S82)

13 A declaração da Smithsonian pode ser encontrada em http://mit.irr. org/smithsonian-institutionstatement-on-book-ofmormon. No mesmo site, há também uma declaração da National Geographic Society sobre o Livro de Mórmon, similar à da Smithsonian, que pode ser lida em http://mit.irr org/file/national-geographicsociety-statement-on-bookof-mormon. Para uma visão geral da controvérsia, ver http://mit.irr.org/scientificsearch-nephite-remains. 
No Livro de Mórmon, a primeira ilustração mostra Jesus Cristo; a segunda, Joseph Smith. A vida de Joseph Smith foi o tema de meu terceiro encontro com as missionárias. Numa das salas onde as crianças participam de recreações durante os encontros de domingo, depois de fazermos uma oração, assistimos a um filme sobre Joseph Smith.

O filme começa com a infância de Joseph Smith, desiludido com todas as religiões a que tentara pertencer. $O$ narrador anuncia então que em meados de 1820, sozinho em um bosque próximo à sua casa, Joseph se ajoel ha e pede a Deus que o oriente. Logo aparece uma luz e surgem, então, Deus e seu filho, Jesus Cristo. Diz o narrador que Deus recomenda a Joseph Smith que não entre para nenhuma das igrejas existentes, todas erradas, e cuide de fundar a verdadeira Igreja de Jesus Cristo, restaurando seu evangelho e acabando com a apostasia que vigorava desde a morte do último apóstolo.

Em seguida, o filme avança três anos: depois de suas orações noturnas, Joseph Smith é abordado pelo Anjo Morôni, que Ihe revela a existência de um livro escondido, gravado em placas de ouro e contendo um relato sobre os antigos habitantes do continente americano. Junto com as placas, encontraria duas pedras encastoadas em prata — Urim e Tumim — que haviam sido preparadas por Deus para serem usadas na tradução do livro. Nesse momento, diz o narrador, a mente de Joseph Smith se abriu a ponto de Ihe permitir visualizar o local exato onde as placas estavam: no Monte Cumorah, perto da vila de Manchester, no Estado de Nova York.

O filme avança então para 1827, quando finalmente Joseph encontra as placas, o Urim e o Tumim, e começa imediatamente a tradução, num quarto fechado, absorvido pelo trabalho. Após certo tempo de trabalho, conta o filme, Joseph e Oliver (seu amigo fiel, que se tornaria o segundo Elder da IJCSUD e a primeira testemunha oficial da veracidade do Livro de Mórmon) são perseguidos e se mudam para a fazenda de um amigo, na primeira de muitas fugas. Em pouco mais de dois meses, terminam o trabalho de tradução. Estava pronto o Livro de Mórmon. O filme mostra o Anjo Morôni aparecendo em seguida a alguns amigos de Joseph, para que eles pudessem corroborar a veracidade do livro (o mesmo Livro de Mórmon que recebi das mãos das Sisters que me fizeram as palestras iniciais).

Depois disso, a vida de Joseph Smith é breve, mas intensa: antes de ser assassinado, aos 38 anos, já reunira milhares de seguidores.

\section{DA LINHAGEM DE DEUS}

Já contei que, logo em nosso primeiro encontro, as missionárias me deram o Livro de Mórmon e me sugeriram perguntar a Deus se o Livro era verdadeiro.

Deus, explicaram meus amigos mórmons, comunica-se frequentemente 
com os membros da Igreja. Todas as decisões da Igreja são tomadas diretamente por Ele. Há, por exemplo, um dia da semana reservado à tomada de decisões pelo presidente da Igreja no que tange à sua organização: nesse dia, ele se encerra numa sala de onde sai com tudo resolvido; Deus fala através dele.

A continuidade entre a vida atual e a vida eterna é mais perceptível na instituição-chave do mormonismo, o primeiro degrau rumo à santidade e, ao mesmo tempo, o último elo na cadeia hierárquica da Igreja: a família. Certo dia, uma fiel da Igreja me explicou que o ser humano é um estágio embrionário de Deus, que um dia também foi um homem, com pai, mãe, avô etc. Segundo ela, "traçando nossa árvore genealógica, podemos chegar até Adão-e assim por diante, até Deus".14

Depois de uma Reunião, perguntei a Jonas sobre o Reino Celestial. "É igual a aqui, só que perfeito" ele me disse. "Como assim?", perguntei. "Está vendo aquela árvore?", Jonas me perguntou. "No Reino Celestial tem essa mesma árvore, só que lá ela é perfeita. Não tem cupim, não tem fruta podre, não tem galho seco, nada disso"15. Indaguei-Ihe então como seríamos nós no Mundo Celestial. "Igual a aqui", respondeu, "só que perfeitos. O mesmo corpo, só que sem nenhuma doença, nenhum problema. ${ }^{16}$ Vamos viver na plenitude da alegria, junto das nossas famílias. E lá vamos receber a mesma glória de Deus. Você sabe o que isso quer dizer, né? Que vamos virar deuses!"

No mormonismo, como Jonas me explicou, o ser humano não é o oposto de Deus, assim como o Céu não é o oposto da terra. Todo santo dos últimos dias pertence à linhagem de Deus, é seu descendente direto. Joseph Smith ensina: "O próprio Deus já foi como somos agora - ele é um homem exaltado, entronizado em céus distantes" (Ensinamentos do profeta Joseph Smith, pág. 336). Somos todos, portanto, da linhagem de Deus, irmãos mais novos de Jesus - que, por sua vez, progrediu até tornar-se um Deus (Princípios do evangelho).

Partimos da família para traçar a genealogia que nos define como descendentes diretos de Deus; e ela também nos liga ao profeta - a família é a unidade fundamental da Igreja, a organização em torno da qual (e para a qual) é construída toda a sua estrutura, como podemos observar no gráfico extraído do site oficial da Igreja no Brasil: A Primeira Presidência $\rightarrow$ O Quórum dos Doze $\rightarrow$ As Presidências de Área $\rightarrow$ A Presidência da Estaca $\rightarrow O$ Bispo / O Presidente de Ramo $\rightarrow$ Família (membros)

Mas a família, nesse caso, não se limita aos parentes que nos rodeiam. No mormonismo, as famílias podem ser eternas, como veremos a seguir.

\section{“AS FAMÍLIAS PODERÃo SER ETERNAS"}

Num domingo, assisti a uma aula cujo tema era "As Famílias Poderão Ser Eternas". Logo no começo, depois de um hino sobre esse tema, a professora pediu-
14 Cannell relaciona essa genealogia com a própria concepção mórmon do tempo cronológico, quando afirma que "os mórmons não ensinam apenas que somos literalmente filhos do Pai Celestial (...); acreditam também que o próprio Deus é, em última instância, um elo a mais numa cadeia de descendência. Deus teve um pai (...) e o pai de Deus também deve ter tido um pai, e assim por diante, em um regresso infinito. A eternidade não se define apenas pela genealogia humana, mas também pela divina, na qual a descendência humana aparece simplesmente interposta como um elo numa longa cadeia, ou melhor, numa rede. Deus gerou mortais que se tornaram deuses, que por sua vez foram os progenitores de outros mundos, outros mortais, outros deuses. Por essa razão, toda a concepção do tempo é alterada no Mormonismo". (2005: 349)

15 Cannell (2005) relata uma conversa semelhante que teve com duas amigas mórmons, durante sua pesquisa. A primeira, que adorava chocolate, Ihe dizia que no mundo celestial haveria chocolate, mas ninguém teria que se preocupar com peso; a outra, matemática, que lá ela poderia discutir a teoria da relatividade com Einstein. (2005: 336)

16 No mormonismo, como bem definiu Cannell (2005) não existe a separação entre corpo e espírito, tão cara ao cristianismo ortodoxo. No livro Princípios do Evangelho, lê-se: "Seres espirituais possuem a mesma forma física que os mortais, apenas que o corpo espiritual é perfeito em sua forma. (...) Eles possuem os mesmos apetites e desejos que tinham quando viveram sobre a Terra. Todos os espíritos têm a forma adulta 
-me para ler um parágrafo do livro Princípios do evangelho intitulado A família eterna: "Nossa família poderá ficar junta para sempre. Para gozar essa bênção, devemos casar-nos no templo. Quando as pessoas se casam fora do templo, 0 casamento termina quando o marido ou a mulher morrem. Já quando nos casamos no templo pela autoridade do Sacerdócio de Melquisedeque, casamo-nos para o tempo e a eternidade." (: 222)

A aula prosseguiu até um membro recente da Igreja perguntar: "E se as pessoas casadas no templo quiserem se separar depois?" A pergunta constrangeu visivelmente a professora, que respondeu "O casamento não foi feito para ser terminado. Em casos muito extremos, como uma infidelidade imperdoável, pode acontecer. Mas estou falando de casos extremos. Conheço casais que casaram no templo e se separaram, mas com filhos. Aí é diferente, porque os filhos já nascem sob o convênio. Por exemplo, eu tenho uma amiga que vai ter um filho, com outro homem, que vai nascer sob o convênio do primeiro casamento dela". A resposta deixou o novo membro confuso, e a professora explicou: "Ela está selada ao primeiro marido. Assim, mesmo que o filho seja de outro homem, estará selado com ela e com o primeiro marido dela, porque ela está selada a ele como uma família, entendeu? Por exemplo, se você separa e se casa de novo, levando filhos do primeiro casamento, eles vão ter que escolher com qual casal vão querer ser selados, se com o pai e a nova mulher ou com a mãe e o novo marido."

A possibilidade de uma família eterna é um dos pilares do mormonismo: consagrando sua união no templo, o casal garante a continuidade do matrimônio para além da vida terrena - a união não é apenas "até que a morte os separe." A família se completa com o selamento dos filhos ao casal; assim, todos podem viver juntos na vida pós-mortal, num dos destinos possíveis depois do fim da vida terrena - destinos determinados pela qualidade da nossa passagem pela Terra. Os que fazem parte da Igreja e sempre se conformam ao seu padrão seguem para o Reino Celestial; àqueles que, depois de batizados, não seguem o padrão, ou que não têm a oportunidade de integrar a Igreja durante a passagem pela Terra, é reservado o Reino Terrestrial; e os que tiverem a oportunidade de fazer parte da Igreja mas mesmo assim a rejeitarem irão para o Reino Telestial. ${ }^{17}$ Aqueles que pecam, além de rejeitarem o Evangelho, seguem para as Trevas Exteriores e lá permanecerão para todo o sempre, pois lá-ao contrário dos Reinos Telestial e Terrestrial - não chegam os missionários espirituais.

Quando eu quis saber dos missionários espirituais, a professora respondeu que existem para dar a quem não teve a chance de se batizar ou de se casar durante a existência terrena, a oportunidade de habitar o Reino Celestial, junto com suas famílias, na vida pós-mortal. Mas os parentes mortos também podem obter esse acesso sendo batizados ou casados "por procuração", ela me explicou. A primeira etapa deste trabalho é a localização de algum registro do parente
(...) após a morte, mesmo quando morrem crianças". (Princípios do Evangelho: 278)

17 A medida que define —em última instância - o direcionamento a cada um dos reinos é o grau de glória obtido por cada um durante sua vida terrena. 
falecido. Para tanto, geralmente pede-se ajuda ao serviço de genealogia da Igreja. A Igreja de Jesus Cristo dos Santos dos Últimos Dias controla o maior banco de dados genealógicos do mundo, alimentado por diversos softwares de busca familiar (chamados "family tree", árvore genealógica), cujo serviço é gratuito para os membros. Nesse banco de dados, encontram-se registros microfilmados de uma infinidade de certidões de nascimento, casamento, batismo e qualquer outro documento que comprove a existência de uma determinada pessoa. Se um membro da Igreja está buscando registros que provem a existência de, suponhamos, seu tataravô, que viveu duzentos anos atrás em algum país longínquo, a primeira coisa que deve fazer é enviar, através de seu bispo, o nome deste antepassado para a sede da Igreja, em Salt Lake City. ${ }^{18}$

De posse dos documentos, o parente vivo parte então para a etapa seguinte do processo. Se for um casamento, e se os antepassados em questão não tiverem sido membros da Igreja (o que é mais comum), antes é preciso batizá-los. 0 batismo dos mortos, ou batismo vicário, só pode ser feito no Templo - ao contrário do batismo dos vivos, que pode ser feito em qualquer unidade da Igreja. O princípio é o mesmo do casamento: os mortos precisam ser representados por um vivo. Assim, alguém que estiver se batizando leva junto consigo algo que remeta ao antepassado que se quer batizar e os dois são batizados juntos. No casamento também: o casal que celebra as bodas no templo leva consigo as certidões recuperadas do casal já falecido e os dois pares casam-se ao mesmo tempo. ${ }^{19}$ Esse processo pode se repetir indefinidamente: um casal que conheci me contou que, durante seu casamento no Templo de São Paulo, casaram-se por mais oito casais de mortos, todos ancestrais de membros da Igreja. O mesmo ocorre em quase todo casamento no Templo: depois que o casal contrai núpcias, representa o casamento de casais já mortos, encomendados por descendentes destes casais.

Certa vez, numa conferência internacional da Igreja que assisti, um membro do Quórum dos Doze Apóstolos falou sobre a importância da pesquisa dos ancestrais: "Nossos antepassados precisam de ajuda. Precisam dos convênios que os libertarão da prisão espiritual. As novas tecnologias aumentam nossa obrigação. De quem muito recebe, muito se exige." Em seguida, contou, chorando, que sonhou com o nome de um antepassado de 300 anos atrás, concluindo imediatamente que o sonho era um pedido de ajuda. A partir daí, não descansou até conseguir cópias da certidão de nascimento desse antepassado e batizá-lo no templo. Depois disso, sentiu-se aliviado: "Sabia que a partir de então ele obteve a chance de se salvar." ${ }^{20}$

Quem batiza os seus antepassados, completando a linhagem com os ancestrais, chega mais perto de provar que é filho literal de Deus, aumentando assim as chances dele e de seus parentes tornarem-se também deuses na vida pós-
18 Aparentemente, os registros genealógicos e a busca por ancestrais são também importantes para outras práticas religiosas. Sobre isso, ver o caso da (re)conversão de judeus no Suriname - e o modo como, nessa situação, os papéis de registro criam parentesco - tal como descrito por Loureiro (2014).

19 É importante ressaltar que o batismo e o casamento dos mortos só se efetiva se aceito pelos beneficiários. Segundo uma fiel, «As pessoas estão lá, no Céu, separadas, porque não fizeram o convênio no Templo; aí alguém aqui as casa, supondo que aceitaram ser batizadas. Aí eles veem se querem ficar juntos de novo ou não. Porque podem estar bem separados e aí negam esse casamento. Mas, se quiserem ficar juntos, quando alguém os casa aqui eles automaticamente se juntam lá no Céu.»

20 Cannell (2005) também vivenciou situações desse tipo e fez a seguinte observação: "É especialmente apropriado para os mórmons chorarem quando falam de genealogia e de história familiar, pois sua religião os obriga não só a rastrear seus parentes mortos como também a amá-los, mesmo aqueles ancestrais distantes que nunca chegaram a conhecer". (2005: 345) 
-terrena. A ontogenética mórmon resolve assim, na prática, a unidade divina do cristianismo. Os convertidos viverão com Deus porque são da sua família, seus descendentes diretos. Viverão com Deus porque também serão deuses.

\section{CONSIDERAÇõ̃S FINAIS}

Em um dado momento da pesquisa, Sister Moraes e Sister Purey me indagaram sobre a natureza de um trabalho acadêmico. Quando conversávamos sobre os rituais envolvidos neste percurso, Sister Moraes se mostrou especialmente interessada na parte em que o trabalho deve ser defendido. "Defender de quê?", ela me perguntou. "Das críticas", respondi. "Mas por que eles vão te criticar? Porque a sua tese não é verdadeira?" "Mais ou menos isso", respondi. "Então você não precisa se preocupar", ela me disse. "Porque se o Livro de Mórmon é verdadeiro e esta é a Igreja verdadeira, então o seu trabalho também vai ser verdadeiro."

Depois que acabei de ler o Livro de Mórmon, surpreendi-me pensando várias vezes se deveria ou não perguntar a Deus se ele era verdadeiro. Receei, nesse momento, estar seguindo os passos de Dan Sperber - que recusou o convite, feito pelo velho Filaté, para caçar um dragão e em seguida se questiona quanto a isso: “(...) por que eu deveria recusar? Tinha medo de enfrentar o dragão? Não sabia que dragões não existem? Sabia perfeitamente, mas ainda assim..." (1982:82). ${ }^{21}$ De fato, eu simplesmente acreditava que Deus não responderia, mas, diante da minha própria incapacidade de perguntar, concluí que, ao contrário dos meus amigos mórmons, eu não sabia. A partir daí a questão era: como contemplar a possibilidade de haver ou não uma resposta divina sem que isso afetasse o resultado final da pesquisa? Ou, em outras palavras, como construir uma etnografia que não presumisse a impossibilidade de realmente haver uma resposta sem supor, em contrapartida, que sua existência fosse óbvia?22

A literatura antropológica está repleta de relatos de experiências que poderiam ser chamadas de "místicas", como o de Evans-Pritchard, que afirma ter visto a bruxaria "apenas uma vez" (1976: 42); ou de Coldman (2003), que ouviu os "tambores dos mortos" ao acompanhar um grupo que realizava o despacho dos assentamentos de uma filha de santo recém-falecida. Enquanto a experiência "mística" de Evans-Pritchard não o impediu de afirmar que "da forma como os Azande os concebem, bruxos não podem evidentemente existir" (1976: 83), Coldman foi além e definiu um caminho a ser seguido pelo pesquisador que vivencie uma dessas situações. Logo após relatar a sua experiência, diz que devemos "afastar de antemão as duas explicações mais fáceis, que, ambas realistas a seu modo, logo interromperiam qualquer trabalho de reflexão mais sério: a mística (...) e a materialista (...)" (2003: 450). O que importa, para o autor, não é tanto a natureza real da experiência, mas a afecção — no sentido que Jeanne
21 É curiosa a comparação entre esta análise de Sperber e a de Ingold (2011). Em um artigo intitulado justamente "Caminhando com dragões", Ingold nos apresenta o caso de um monge medieval que, ao sair para um passeio, encontra um dragão que só ele é capaz de ver e que - aqui está o mais importante da história - exerce um efeito sobre a sua vida. $\mathrm{O}$ autor nos diz que "não é como se o monge da nossa história estivesse cara a cara com alguma criatura que, com o benefício do retrospecto científico, nós modernos pudéssemos reconhecer como uma espécie de réptil" (2011: 18) já que "não há dragões (...) nas taxonomias científicas. A questão não é só que eles não existem no novo livro da natureza, mas que não podem existir, uma vez que sua constituição histórica ficcional não se encaixa nesse projeto de classificação. Os dragões, junto com outros seres que surgem, ou cuja presença é sentida no nosso mundo, podem ser contados, mas não categorizados. E é claro que também não podem ser localizados de forma precisa, como num mapa cartográfico" (2011: 25). O fenômeno deveria, assim, ser observado antes "como um nó num emaranhado de descrições, histórias, chamados, visões e outras observações interligadas, nenhuma ontologicamente superior às outras, ou em algum sentido mais 'real' do que outras, qualquer criatura — poderíamos dizer - não é uma coisa viva, como a instância de certa forma de estar vivo, mas cada qual, para a mente medieval, abriria um caminho para a experiência de Deus" (2011: 23).

22 Algo que Holbraad leva às últimas consequências em sua 
Favret-Saada (2005) dá ao termo - que ela provoca. Trata-se tanto de se deixar afetar pelas mesmas forças que afetam os nativos, quanto (o que talvez seja o mais importante) de conseguir usar isso em prol da etnografia, tornando assim o próprio texto antropológico permeável ao efeito de tais forças.

No caso do presente artigo, julgo poder dizer que a distinção entre crença e saber é mais etnográfica que epistemológica: digo que os mórmons sabem porque foi isso que eles me disseram. Ainda que se possa argumentar que na base desse saber está uma crença (em Deus, por exemplo), o resultado final da equação - que depende da confirmação divina — é a verdade unívoca, que pode levar (quase) qualquer um a colocar suas próprias crenças em dúvida. Ou, como nos diz Jean Pouillon,

na verdade, aquele que crên na existência de Deus não só não sente necessidade de dizer que crê como sequer sente a necessidade de crer, justamente porque, aos seus olhos, essa existência não é duvidosa: não é objeto de crença, mas de percepção. Ao contrário, transformá-la em objeto de crença, anunciá-la, é admitir a possibilidade da dúvida (...) (1979: 2).

Desde que Bruno Latour (2005) reafirmou que a etnografia deve respeitar o fluxo de informações nativas, sem cortá-lo com explicações que Ihe sejam extrínsecas, sabemos que nós, antropólogos, devemos nos permitir ser afetados pelo que sucede no campo; que não devemos circunscrever a realidade nativa em categorias pré-concebidas, encapsulando os que nos recebem em campo em alguma moldura antropológica; e que, ao invés disso, precisamos postular, nas palavras de Viveiros de Castro, "a equivalência de direito entre os discursos do antropólogo e do nativo, bem como a condição constituinte desses discursos" (2002: 125). Mas então, o que fazer com a minha relutância? O fato é que não fui capaz de perguntar a Deus se o Livro de Mórmon era verdadeiro, o que seria a última escala na minha trajetória de pesquisadora-e a única etapa que não consegui cumprir. Por muito tempo, minha falta de coragem (ou de vontade) de fazer a pergunta representou um problema. Só no final da minha pesquisa, percebi que estava ali justamente em busca de novos problemas, ou seja, que a minha relutância poderia apontar um caminho. Não saber efetivamente se haveria uma resposta tornou meu trabalho de descrição mais complexo e, penso eu, etnograficamente mais completo. Pensando retroativamente, qualquer resposta que eu lograsse obter poderia se tornar um componente estranho à minha descrição; ou, melhor dizendo, a resposta a uma questão deslocada de sentido.

Mas a mesma questão pode ser vista de outra maneira: ao evitar a pergunta, posso ter evitado também a afecção por forças intrínsecas à composição da pessoa mórmon. Entretanto, se tomarmos a ideia de Favret-Saada de que "ser análise do que ele denomina "ontografia do conceito de verdade" (2003: 45) do Ifá cubano. Porém, o objetivo do autor não é somente revelar os pressupostos ontológicos que subjazem os enunciados nativos, mas fazer uma "tentativa de extrapolar abstrações analíticas a partir do material etnográfico, em lugar de soterrá-lo sob uma pilha de conceitos filosóficos ocidentais" (idem: 46). 
afetado" não me colocaria na posição de "crente" (ou, melhor dizendo, "sábio"), mas sim de alguém "sujeito às mesmas forças" que meus interlocutores mórmons, é possível especular que, se eu tivesse feito a pergunta, meu problema seria - ainda-o de manter-me em uma posição próxima e distante o suficiente para que ainda fosse possível transformar (ou traduzir) essa experiência "mística" numa experiência de conhecimento etnográfico.

Sabemos que a etnografia é, por definição, uma imersão na imprevisibilidade. Pois foi nessa seara, da incerteza quanto à possibilidade de haver ou não uma resposta, que caminhei. Penso, porém, que minha relutância levou-me a pensar seriamente sobre a postulada crença nativa e a possível descrença antropológica, e uma das conclusões a que cheguei é que nenhuma delas pode ser considerada a pedra fundamental de uma relação de deliberações mútuas ${ }^{23}$. Como diz Pouillon e como eu mesma pude verificar na minha pesquisa, não se pode atribuir o postulado de crença a algo que se apresenta como um saber. E, perante o que se apresenta, não cabe ao antropólogo deliberar se acredita ou não, mas sim pensar sobre o que isso representa para a sua pesquisa, quais caminhos indica a seguir. Ou seja, o problema é de descrição, um problema que, embora possa parecer simples, é na verdade extremamente complexo. Pois, ao menos para mim, a grande tarefa de escrever sobre religião é esta: fazê-lo sem tomar como pressuposto nem a existência, nem a inexistência das entidades sobrenaturais com as quais lidarei.

Clara Flaksman é pós-doutoranda do Programa de Pós-Graduação em Ciências Sociais da Universidade Federal da Bahia.

\section{REFERÊNCIAS BIBLIOGRÁFICAS}

AMORIM, Nádia Fernanda Maia de

1986 Os Mórmons em Alagoas: religião e relações raciais. São Paulo, FFLCH/ USP-CER; Coleção Religião e Sociedade Brasileira Vol. 3.

\section{BATESON, Gregory}

1972 "Social Planning and the Concept of Deutero-Learning". In: Steps to an Ecology of Mind. Nova York, Ballantine Books. pp. 159-176.

1972 "Toward a Theory of Schizofrenia". In: Steps to an Ecology of Mind. Nova York, Ballantine Books. pp. 201-227. 
CANNELL, Fenella

2005 "The Christianity of Anthropology". The Journal of the Royal Anthropological Institute, Londres, Royal Anthropological Institute, v. 2, n. 11: 335-356.

2013 "The Blood of Abraham: Mormon Redemptive Physicality and American Idioms of Kinship". Journal of the Royal Anthropological Institute, vol. 19, issue S1: S77-S94.

2017 "Mormonism and Anthropology: On Ways of Knowing". Mormon Studies Review, vol. 4: 1-15.

CATELA, Gilda Verónica Ludmila da Silva

1994 Juventude Divino Tesouro: estudo comparativo sobre jovens mórmons das Igrejas San Martin (Rosario-Argentina) e Botafogo (Rio de Janeiro-Brasil). Rio de Janeiro, dissertação de mestrado, Universidade Federal do Rio de Janeiro.

CRAPANZANO, Vincent

2000 Serving the Word: Literalism in America from the Pulpit to the Bench. Nova York, The New Press.

2005 "A cena: lançando sombra sobre o real". Mana, vol. 11, n. 2: 357-383.

EVANS-PRITCHARD, E. E.

2005 Bruxaria, oráculos e magia entre os Azande. Rio de Janeiro: Jorge Zahar Editor.

FAVRET-SAADA, Jeanne

2005 "Ser afetado". Cadernos de Campo, n. 13: 155-161.

FLAKSMAN, Clara

2007 Santos dos Últimos Dias: etnografia e pesquisa mórmon. Rio de Janeiro, dissertação de mestrado, Universidade Federal do Rio de Janeiro.

GIUMBELLI, Emerson

2011 "A noção de crença e suas implicações para a modernidade: um diálogo imaginado entre Bruno Latour e Talal Asad". Horizontes Antropológicos, ano 17, n. 35: 327-356.

GOLDMAN, Marcio

2003 "Os tambores dos mortos e os tambores dos vivos. Etnografia, antropologia e política em Ilhéus, Bahia". Revista de Antropologia, v. 46, n. 2: 445-476. 
HOLBRAAD, Martin

2003 "Estimando a necessidade: os Oráculos de Ifá e a

Verdade em Havana". Mana, 9(2): 39-77.

INGOLD, Tim

2011 "Caminhando com dragões: em direção ao lado selvagem". In STEIL,

Carlos Alberto e CARVALHO, Isabel de Moura (orgs.). Cultura, percepção e ambiente: diálogos com Tim Ingold. São Paulo, Terceiro Nome.

LATOUR, Bruno

2004 'NNão congelarás a imagem', ou: como não desentender o debate ciência-religião". Mana, 10(2): 349-376.

2005 Reassembling the Social: An Introduction to Actor-NetworkTheory. Oxford, Oxford University Press.

2013 An Inquiry into Modes of Existence. Cambridge, Harvard University Press.

LOUREIRO, Thiago de Niemeyer Matheus

2014 "Artefatos genealógicos e ancestralidade judaica no

Suriname". Teoria e Cultura. Revista do programa de Pós-

Graduação em Ciências Sociais da UFJF, v. 9, n.2: 41-52.

NEEDHAM, Rodney

1972 Belief, Language and Experience. Chicago, The University of Chicago Press.

POUILLON, Jean

1979 "Remarques sur le verbe croire". In IZARD, Michel e SMITH, Pierre (orgs.). La Fonction symbolique. Paris, Éditions Gallimard. pp. 43-51.

TAYLOR, Charles

2007. A Secular Age. Cambridge: Harvard University Press.

SPERBER, Dan

1982 Le Savoir des anthropologues. Paris, Hermann.

VEYNE, Paul

1984 Acreditavam os gregos em seus mitos? Ensaio sobre a imaginação constituinte. São Paulo, Brasiliense.

VIVEIROS DE CASTRO, Eduardo

2002 "O nativo relativo". Mana, vol. 8, n. 1: 113-148. 
PUBLICAÇõES DE A IGREJA DE JESUS CRISTO dOS SANTOS DOS ÚLTIMOS DIAS

O Livro de Mórmon - Outro Testamento de Jesus Cristo

O Testemunho do Profeta Joseph Smith

Princípios do Evangelho

O Plano de Nosso Pai Celestial

Guia da Família 
On Knowing and Believing:

The Book of Mormon

\section{ABSTRACT}

This article is fruit of a year-long field experience at a Mormon church in Rio de Janeiro, Brazil. Its main objective is to describe the manner in which these mormons demonstrate their experience with the divine: as a form of knowledge. My intent is to discuss the opposition between belief and knowledge in Anthropology, and the role of the ethnographer in fieldwork.

Recebido em 20 de maio de 2016. Aceito em 28 de setembro de 2017.

\section{KEYWORDS}

Mormons,

Ethnography, Belief, Knowledge, Research 